\title{
Income disparity in southeastern Mexico: A reflection from economic indicators
}

\section{Disparidad del ingreso en el sureste de México: Una reflexión a partir de indicadores económicos}

\author{
SALVADOR-GARCÍA, Yazmin Denisse †, MAY-GUILLERMO, Erika Guadalupe* and DE LA CRUZ- \\ MAY, Samuel
}

Universidad Juárez Autónoma de Tabasco, Mexico.

Instituto Tecnológico Superior de la Región Sierra, Mexico.

Universidad Intercultural del estado de Tabasco, Mexico. ID $1^{\text {st }}$ Author: Yazmin Denisse, Salvador-Garcia / ORC ID: 0000-0003-3047-7558, Researcher ID Thomson: S-7586-2018,
CVU CONACYT ID: 824554

ID $1^{\text {st }}$ Co-author: Erika Guadalupe, May-Guillermo / ORC ID: 0000-0001-5403-9849, Researcher ID Thomson: W-43932019, CVU CONACYT ID: 366439

ID $2^{\text {nd }}$ Co-author: Samuel, de la Cruz-May / ORC ID: 0000-0001-9180-6349, Researcher ID Thomson: ABD-3123-2020, CVU CONACYT ID: 862273

DOI: $10.35429 / J F E .2020 .7 .4 .11 .22$

Received July 15, 2020; Accepted December 30, 2020

\begin{abstract}
The objective of this document is to analyze the distribution of income in the states of the southeast region of Mexico during the period 2010-2016, to identify the levels of inequality in economic matters. For this, a documentary, descriptive and longitudinal investigation was carried out, analyzing six economic indicators reported by the Consejo Nacional de Evaluación de la Política de Desarrollo Social (CONEVAL) for the period studied: 1) Gini coefficient, 2) population in poverty situation, 3) vulnerable population by income, 4) population in extreme poverty, 5) population with income below the extreme poverty line by income and 6) population with income below the income poverty line. The results indicate that Chiapas, Guerrero and Oaxaca were the most vulnerable states due to low income levels, high poverty in general, and prevailing inequality in the region. In contrast, the state with the least economic vulnerability was Quintana Roo. The main contribution of the study lies in the identification of the poorest and most vulnerable states in the southeast of Mexico, as well as in the formulation of recommendations for the better distribution of income and poverty reduction in the analyzed region.
\end{abstract}

Distribution, Income, Inequal

\begin{abstract}
Resumen
El objetivo del presente consiste en analizar la distribución del ingreso en las entidades federativas de la región sureste de México durante el período 2010-2016, para identificar los niveles de desigualdad en materia económica. Para ello, se realizó una investigación documental, descriptiva y longitudinal, analizando seis indicadores económicos reportados por el Consejo Nacional de Evaluación de la Política de Desarrollo Social (CONEVAL) para el período estudiado: 1) Coeficiente de Gini, 2) población en situación de pobreza, 3) población vulnerable por ingreso, 4) población en pobreza extrema, 5) población con ingreso inferior a la línea de pobreza extrema por ingresos y 6) población con ingreso inferior a la línea de pobreza por ingresos. Los resultados indican que, Chiapas, Guerrero y Oaxaca fueron los estados más vulnerables debido a los bajos niveles de ingreso, a la alta pobreza en general y a la desigualdad imperante en la región. En contraste, el estado con menor vulnerabilidad económica fue Quintana Roo. La principal aportación del estudio radica en la identificación de los estados más pobres y vulnerables del sureste de México, así como en la formulación de recomendaciones para la mejor distribución del ingreso y reducción de la pobreza en la región analizada.
\end{abstract}

Distribución, Ingreso, Desigualdad

Citation: SALVADOR-GARCÍA, Yazmin Denisse, MAY-GUILLERMO, Erika Guadalupe and DE LA CRUZ-MAY, Samuel. Income disparity in southeastern Mexico: A reflection from economic indicators. RINOE Journal-Financial Economy. 2020. 4-7:11-22.

\footnotetext{
* Correspondence to Author (Email: saoridenise@ hotmail.com)

$\dagger$ Researcher contributing first author.
} 


\section{Introduction}

In Mexico, each region has conditions for its development by virtue of its own characteristics, resources and infrastructure. In a territory delimited by historical, economic and cultural regions, there is a great diversity of natural and human resources, which enable production from specialization, generating comparative advantages. However, the economic and social inequality that exists is notorious (Secretariat of Agriculture, Livestock, Rural Development, Fisheries and Food of Mexico [SAGARPA], 2011).

At the beginning of this century, Mexico was classified by the Economic Commission for Latin America and the Caribbean (ECLAC) among countries with high levels of inequality, on a par with countries such as Nicaragua, Dominican Republic, Chile, Guatemala, Paraguay, Argentina, Bolivia, Brazil, Honduras and Colombia (ECLAC, 2019). Economists suggest that the concentration of income in a small number of inhabitants violates economic growth (Barcelata, 2008), because in countries with high levels of inequality there is a tendency to implement economic policies that only benefit the social sectors with greater power, instead of looking at the large groups of population that have the lowest income levels (Sánchez, 2009).

In Mexico, these phenomena have caused social erosion, an imbalance that generates more Mexicans without access to heritage, health and education (Ordóñez, 2018). The creation of jobs and the improvement of working conditions are utopias that have only remained as a hope for nationals, since trade openness, the contraction of wages and low social security coverage collide with the development of the population (Pozas, 2010).

For this context, Household Income, Gross Domestic Product and Level of Economic Activity suggest a diagnosis of the territories, which reflects their levels of consumption, employment and well-being (Vielma, 2011), at this point the economic policy making Using an ethical and social judgment, it aims to reduce inequality gaps and create opportunities for all Mexicans (Planning Committee for the Development of the State of Tabasco [COPLADET], 2019).
Historically, in the second half of the 20th century, projects necessary for the construction of highways, bridges and basic infrastructure were carried out in the southeast of Mexico; This work is currently not finished, since there are areas that are isolated and difficult to access (Capdepont-Ballina \& MarínOlán, 2014).

On the other hand, tourism has been one of the activities that at the national level has generated income and jobs, and in the region it has not been an exception, for example, the progress of Cancun represented a strategy for the development of the services sector and currently generates millions of income for the country (Medina-Argueta \& Palafox-Muñoz, 2019); Thus, tourism begins to have relevance in Mexico, as an economic phenomenon that facilitates obtaining the necessary foreign exchange for the acquisition of capital goods in support of industrialization (Gutiérrez-Pérez et al., 2014).

Similarly, another important activity is energy, represented by the extraction of oil and natural gas, which created development poles in the seventies and eighties in Veracruz, Tabasco and Campeche (Guzmán-Sala, Mayo-Castro, Pérez - Sánchez, 2012).

Livestock and agriculture in the southeastern region of Mexico supplied the country with meat, fruits, vegetables and primary dairy products (Ministry of Agrarian, Territorial and Urban Development [SEDATU], 2014). However, when referring to the impacts that the economic growth of the southeast region has generated in the dimensions of sustainability, it is identified that, in environmental matters from 1970 to date, the externalization of costs has been very evident, reflected in the pollution of the ecosystem and negative effects for primary activities (SEDATU, 2014). 
In addition to this, the distribution of wealth for a long time was considered an unpleasant and politically sensitive issue (Guerrero-de-Lizardi, 2015), because the government actions undertaken by all countries empower women and men, but There are still poverty gaps that must be worked on (Ortiz \& Cummins, 2012). So the concern about the redistribution of wealth in the world is relatively recent; since the priority was economic growth; However, today there is the need to face global challenges in solidarity (OECD, 2018), forging a society with expectations, based on the information provided by the media, so that the media demand on social justice and access to opportunities must be reflected in the fair distribution of income (Esquivel, 2015); Political and social actors have a predominant role in demanding fair conditions for human development (Rosales, 2017). In this order of ideas, social struggles have demanded the distribution of income that is exercised in all sectors of the different ideologies, areas and places where the national, state and municipal agendas have set the issue that concerns this research (Borri, 2009).

On the other hand, social programs have been an important element that has impacted on income distribution in developing countries (Abramo et al., 2019). In some countries, resource transfer programs have been conditioned on households that must have a socially productive behavior, thus reducing poverty rates; unemployment insurance, hiring subsidies and job creation programs have also supported this task (Abramo et al., 2019); This is how economic growth, social policies and the labor market are key to the study of income distribution, which should seek progress towards general economic well-being (Bárcena, 2011).

Given the above, the objective of this document is to analyze the distribution of income in the states of the southeast region of Mexico during the period 2010-2016, to identify the levels of inequality in economic matters. The statistical data object of analysis by indicator, frame each one of the states of the southeast of Mexico: Campeche, Chiapas, Guerrero, Oaxaca, Quintana Roo, Puebla, Tabasco, Veracruz and Yucatán.

\section{Literature review}

\section{Distribution of income in Mexico}

Income or rent refers to the flow of wages, interest, earnings and other things of value received, during a period, by the various monetary agents Samuelson and Nordhaus (2002). In turn, wealth is understood as the set of current, fixed and deferred assets, belonging to a person (Encalada-Encarnación et al., 2018). Both can be obtained through the elements of production: land, labor, capital and organization (Ministry of the Economy [SE], 2020).

The distribution of wealth or income is the way in which the total product generated by a country is distributed between workers and employers (Moreno, 2013). According to ECLAC (2019), income distribution creates an extremely powerful social entity, which owns wealth from its origin, or has expropriated it from others, and distributes it in the way that entity thinks it is. It is convenient (ECLAC, 2019; Girondella, 2008).

According to Tezanos et al. (2013) income distribution is a trigger for economic development. Therefore, the way it is distributed has been a relevant issue for the economy of any country or region (Campos \& Monroy-GómezFranco, 2016).

However, at the global level one of the biggest claims today is the distribution of income and it represents one of the main criticisms that have been made of capitalism (Navarrete, 2016), since not being fair it represents a setback in the welfare of all or most of the population (Tezanos et al., 2013). Income inequality in a nation is described by political, economic and social elements (María et al., 2019; OECD, 2012).

For Moreno (2013) the elements that affect income distribution are, firstly, that the state determines the economic policy that must be followed; secondly, companies also decide with the corresponding autonomous faculty, and lastly households, in their character of consumption units. 
From another perspective, Hernández (2013) mentions that within the economic elements that affect the distribution of income, there is the disparity of wages, given the differential in productivity between the same workers and also with respect to the owners of capital (International Organization of the Labor [ILO], 2017). In this sense, the arrival of a certain group to power always entails the rise of new characters who do not necessarily have the adequate preparation (Hernández, 2013).

From the orthodox theory of economics, it is proposed that inequality in the distribution of income, as well as power, together with market imperfections, influence policies and the design of institutions (Gordillo, 2013). This means that in the markets, resources are not assigned based on efficiency but on other criteria, such as the perpetuity of power of those who already hold it, instead of achieving sustained economic growth with social harmony (Cortes \& de Oliveira, 2010).

Everything worsens, at the time when income is concentrated due to factors such as lack of transparency, abuse of power, granting of privileges, and above all obstacles to freer and fairer competition (Coutiño, 2015). From the political point of view, the discussion of this issue becomes more acute in electoral times, because each candidate from the sectors that support him poses the problem of distribution, suggesting projects in his proposals (Mendoza, 2011).

In the social sphere, there is a critical exposition of the general policy of income redistribution (ECLAC, 2019) and of the role that the State must assume to guarantee the population growth, development and equity (Escutia, 2012). In this regard, Puryear and Mallow (2010) consider that the State has two ways of reducing inequality and poverty, on the one hand, through the provision of high-quality public services and, on the other hand, by implementing economic support programs (Gauna, 2014).
In Mexico, Coutiño (2015) maintains that there is a high degree of economic inequality, since on the one hand it is possible to see the flourishing business environment together with a privileged bureaucrat class, meanwhile, on the other side there is most of the population, Mexicans who live with one or two minimum wages daily (Colegio de México [CM], 2018).

In this regard, Aguilar-Ortega (2011) points out that in Mexico there are regions that concentrate a large part of the income in a small number of people and also areas where the situation is the opposite, generating serious imbalances. For his part, Sánchez (2006) identifies that Chiapas, Guerreo and Oaxaca are the states with the highest levels of income inequality and therefore poverty in the southeast of Mexico.

\section{Income measurement}

Income measurement requires both quantitative and qualitative methods. Therefore, for many years different indicators have emerged to measure inequality and income distribution (Favila \& Navarro, 2017). Among the quantitative methods that exist to calculate the distribution of wealth, we find per capita income, which is obtained by dividing the total GDP generated by a country by its number of inhabitants (Atuesta et al., 2018); and the Lorenz curve that measures the percentage of income corresponding to the percentage of the population (Medina, 2001).

Despite the information provided by these two methods, there is another that has been the most widely applied, called the Gini coefficient, which consists of calculating a factor that according to its proximity to the value 0 indicates absolute equality, while a value closer to unity, it shows greater inequality (Martínez, 2008).

In addition to these methods, the National Council for the Evaluation of Social Development Policy (CONEVAL, 2018), concentrates the results of the Household Income and Expenditure Surveys (ENIGH) regarding indicators of inequality and poverty in Mexico for the years 2010, 2012, 2014 and 2016. Among these indicators, the following stand out: 
- Gini coefficient. Which measures the economic inequality of a society, takes values between 0 and 1 ; a value that tends to 1 reflects greater inequality in income distribution; on the contrary, if the value tends to zero, there are greater conditions of equity in the distribution of income.

- $\quad$ Population in poverty. It locates the person who has at least one social deprivation (in the six indicators of educational backwardness, access to health services, access to social security, quality and spaces of the house, basic services in the house and access to food) and their income is insufficient to purchase the goods and services they require to satisfy their food and non-food needs.

- Vulnerable population by income. This indicator considers the population that does not present social deprivation but whose income is less than or equal to the welfare line.

- Population in extreme poverty. It covers the population that has three or more deficiencies, out of six possible, within the Social Deprivation Index and that, in addition, is below the minimum welfare line; People in this situation have such a low income that, even if they were to dedicate it entirely to purchasing food, they would not be able to acquire the necessary nutrients for a healthy life.

- Population with income below the extreme poverty line by income. It is one who receives an income lower than the value of the food basket per person per month.

- Population with income below the income poverty line. It is the one that receives an income lower than the total value of the food basket and the non-food basket per person per month.
However, these methods are not totally effective if their results are considered absolute truth when measuring the improvement in quality of life (Rivera \& González, 2017); For this reason, in the qualitative approach, the measurement of income distribution is complemented with the Human Development Index, which includes three areas: health, education and access to goods and services (Jáuregui, et al., 2012).

\section{Poverty and economic lag in Mexico}

According to CONEVAL (2014), poverty is defined as a lack of purchasing power to acquire goods and services that satisfy basic needs. Unquestionably, the economic inequality that prevails in Mexico has generated a considerable increase in poverty in recent years (Mora-Rivera \& Morales, 2018)

In this regard, Navarrete (2016) points out that this has generated important social changes in the lifestyles of poor families, which has had an impact over the years, and according to Cortes (2010), it is from the decade of the eighties that as a consequence of the abrupt falls in the income caused by the crises; Poor households resorted to sending their children, youth, the elderly and women who would otherwise remain at home to work and to grouping households to reduce the effect of fixed costs on the family budget (Halter et al., 2014).

By 2015, Mexico had 119,530,753 inhabitants, of which 55.3 million were in poverty (CONEVAL, 2014; National Institute of Statistics and Geography [INEGI], 2015).

Emphasizing in the context of economic inequality, it is necessary to point out that both in the countries and in the territories that comprise it, it is determined by differences in income and consumption (Aguilar, 2016); This is how in the last decade there has been a disparity in the population's living standards (Cortés, 2013).

Statistically, poverty and income inequality are related, there is a positive correlation between levels of poverty and inequality in Mexican states (Mora-Rivera \& Morales, 2018). In other words, if inequality decreases; poverty will decrease faster. 
Today, wealth is rapidly becoming the most important source of power and influence in the world, as the extreme concentration of wealth is the cause of political capture, in other words, excessive and undue influence on the taking of decisions and the democratic processes that this wealth allows the country's elites (Fuentes-Nieva, 2016).

Due to the above, and the other factors that have been described, in national governments there is a tension on the existing statistical results on the distribution of income in developing countries, such as Mexico (Favila \& Navarro, 2017). The gap between the government's point of view on economic performance and the opinions of society is caused not only by the measurements that emerge in the system of national accounts, but also by other variables, notably the consumer price index and the income of families (Favila \& Navarro, 2017).

These measurements are based on the fact that a family has a wealth, in which there are values of some assets, such as a personal business or a residence, which are quantified and through surveys are added in a result of a specific territory Therefore, the importance of studying the distribution of wealth and its role in decisionmaking (Guerrero-de-Lizardi, 2015).

In a general panorama, economic inequality leads to an interest in the implementation of various policies in the search for equity and income distribution in Mexico (Mckenzie \& Rapoport, 2004). Country where a high level of inequality is statistically shown in its southeastern states according to international standards, which in terms of theoretical contributions these indicators can delay the growth of developing countries (Abramo, Cecchini, \& Morales, 2019).

\section{Methodology to be developed}

A descriptive, documentary research with a longitudinal design was carried out. The data was obtained from the 2018 statistical annex of the poverty report in Mexico, published by CONEVAL based on the results of the Household Income and Expenditure Surveys (ENIGH). The indicators considered were:
- Gini coefficient.

- Population in poverty.

- Vulnerable population by income.

- Population in extreme poverty.

- Population with income below the extreme poverty line by income.

- Population with income below the income poverty line.

The unit of analysis corresponds to the results obtained by indicator in each of the states of southeastern Mexico (Campeche, Chiapas, Guerrero, Oaxaca, Quintana Roo, Puebla, Tabasco, Veracruz and Yucatán) during the period 2010-2016. This period was selected in order to observe the most recent and available trends and behaviors of the selected indicators.

For the purposes of the analysis, the states belonging to the southeast of Mexico were listed in alphabetical order and the value obtained in each indicator was recorded according to the year evaluated. Subsequently, the means of each indicator by state were calculated to compare the results.

Likewise, to interpret the Gini coefficient, the values closest to the unit were selected to designate the states with the greatest income inequality; opposite case of those more distant that were considered states with less inequality.

In relation to indicators $2,3,4,5$ and 6 , the highest means were considered to classify the states with the highest levels of poverty and vulnerability; Consequently, the lowest average obtained places the states with the lowest levels of poverty and vulnerability in the southeast region of Mexico.

\section{Results}

In the present research it was identified that, for the indicators under study in the years 2010, 2012, 2014 and 2016, the states of the southeast of Mexico are more vulnerable due to low income levels, high poverty in general and inequality that prevails in the area are: Chiapas, Guerrero and Oaxaca. 
In contrast, the state with the lowest levels of economic vulnerability is Quintana Roo. The results obtained in each indicator are described in the following tables.

In relation to the indicator of economic inequality, presented in table 1, it is observed that the highest average registered in the study period is located in the state of Chiapas with a value of .51 , which indicates that it is the state with higher level of economic inequality, based on the Gini coefficient closest to unity.

However, the states of Oaxaca and Campeche are close to reaching these levels of inequality since they register averages of .50 and .49 respectively. Otherwise, the state of Quintana Roo that registers the lowest average, obtaining a value of .46, which places it with the lowest level of economic inequality in the region.

\begin{tabular}{|l|r|r|r|r|r|}
\hline Federal entity & $\mathbf{2 0 1 0}$ & $\mathbf{2 0 1 2}$ & $\mathbf{2 0 1 4}$ & $\mathbf{2 0 1 6}$ & Average \\
\hline Campeche & .514 & .533 & .500 & .426 & .49 \\
\hline Chiapas & .541 & .535 & .517 & .444 & .51 \\
\hline Warrior & .516 & .533 & .489 & .414 & .49 \\
\hline Oaxaca & .509 & .511 & .513 & .447 & .50 \\
\hline Puebla & .481 & .485 & .572 & .396 & .48 \\
\hline Quintana Roo & .477 & .477 & .494 & .389 & .46 \\
\hline Tabasco & .478 & .516 & .456 & .409 & .47 \\
\hline Veracruz & .533 & .493 & .490 & .440 & .49 \\
\hline Yucatan & .462 & .461 & .511 & .419 & .46 \\
\hline
\end{tabular}

Table 1 Gini coefficient expressed as a percentage corresponding to the states of southeastern Mexico for the period 2010-2016

Source: Prepared based on estimates from CONEVAL (2018)

Regarding the percentage of the population living in poverty, Table 2 shows that the state of Chiapas has the highest percentage in the region, obtaining $76.62 \%$, followed by Guerrero with $66.72 \%$ and Oaxaca with $66.52 \%$; while the lowest percentage corresponding to $34.54 \%$ is registered for the state of Quintana Roo.

\begin{tabular}{|c|c|c|c|c|c|}
\hline Federal entity & 2010 & 2012 & 2014 & 2016 & Average \\
\hline Campeche & 50.505 & 44.664 & 43.588 & 43.768 & 45.63 \\
\hline Chiapas & 78.483 & 74.687 & 76.209 & 77.081 & 76.62 \\
\hline Warrior & 67.571 & 69.696 & 65.218 & 64.407 & 66.72 \\
\hline Oaxaca & 66.987 & 61.937 & 66.750 & 70.401 & 66.52 \\
\hline Puebla & 61.483 & 64.470 & 64.537 & 59.440 & 62.48 \\
\hline Quintana Roo & 34.627 & 38.793 & 35.882 & 28.847 & 34.54 \\
\hline Tabasco & 57.096 & 49.690 & 49.571 & 50.852 & 51.80 \\
\hline Veracruz & 57.579 & 52.644 & 58.005 & 62.160 & 57.60 \\
\hline Yucatan & 48.321 & 48.857 & 45.857 & 41.872 & 46.23 \\
\hline
\end{tabular}

Table 2 Percentage of population living in poverty in the states of southeastern Mexico for the period 2010-2016 Source: Prepared based on estimates from CONEVAL (2018)
According to Table 3, the highest percentage of the vulnerable population by income was registered in the state of Yucatán with $6.35 \%$, while the lowest percentage was found in the state of Oaxaca with $1.84 \%$.

\begin{tabular}{|l|l|l|l|l|r|}
\hline $\begin{array}{c}\text { Federal } \\
\text { entity }\end{array}$ & $\mathbf{2 0 1 0}$ & 2012 & $\mathbf{2 0 1 4}$ & $\mathbf{2 0 1 6}$ & Average \\
\hline Campeche & 4.320 & 5.571 & 3.997 & 4.796 & 4.67 \\
\hline Chiapas & 2.369 & 1.730 & 2.497 & 2.727 & 2.33 \\
\hline Warrior & 1.978 & 2.250 & 2.647 & 3.217 & 2.52 \\
\hline Oaxaca & 1.294 & 1.656 & 2.095 & 2.328 & 1.84 \\
\hline Puebla & 5.567 & 4.221 & 5.120 & 6.206 & 5.28 \\
\hline Quintana Roo & 4.739 & 6.189 & 6.251 & 4.312 & 5.37 \\
\hline Tabasco & 4.132 & 3.006 & 2.349 & 2.594 & 3.02 \\
\hline Veracruz & 4.527 & 3.985 & 5.018 & 4.973 & 4.63 \\
\hline Yucatan & 6.438 & 6.252 & 6.955 & 5.742 & 6.35 \\
\hline
\end{tabular}

Table 3 Percentage of vulnerable population by income in the states of southeastern Mexico for the period 2010-2016 Source: Prepared based on estimates from CONEVAL (2018)

Based on the percentage of the population living in extreme poverty in the states of southeastern Mexico, Table 4 indicates that for the years 2010, 2012, 2014 and 2016, Chiapas is identified as the state with the highest registered percentage corresponding to $32.59 \%$, followed by Guerrero and Oaxaca with percentages of $27.74 \%$ and $26.94 \%$ respectively, while the state of Quintana Roo registered $6.51 \%$, being the lowest percentage of the population living in extreme poverty in the region.

\begin{tabular}{|l|r|r|r|r|r|}
\hline $\begin{array}{c}\text { Federal } \\
\text { entity }\end{array}$ & $\mathbf{2 0 1 0}$ & $\mathbf{2 0 1 2}$ & $\mathbf{2 0 1 4}$ & $\mathbf{2 0 1 6}$ & Average \\
\hline Campeche & 13.784 & 10.448 & 11.063 & 6.657 & 10.49 \\
\hline Chiapas & 38.273 & 32.171 & 31.829 & 28.079 & 32.59 \\
\hline Warrior & 31.830 & 31.711 & 24.452 & 22.962 & 27.74 \\
\hline Oaxaca & 29.245 & 23.318 & 28.334 & 26.880 & 26.94 \\
\hline Puebla & 17.031 & 17.606 & 16.161 & 8.958 & 14.94 \\
\hline $\begin{array}{l}\text { Quintana } \\
\text { Roo }\end{array}$ & 6.426 & 8.413 & 6.979 & 4.237 & 6.51 \\
\hline Tabasco & 13.565 & 14.301 & 11.029 & 11.769 & 12.67 \\
\hline Veracruz & 18.757 & 14.261 & 17.154 & 16.403 & 16.64 \\
\hline Yucatan & 11.720 & 9.832 & 10.686 & 6.148 & 9.60 \\
\hline
\end{tabular}

Table 4 Percentage of the population living in extreme poverty in the states of southeastern Mexico for the period 2010-2016

Source: Prepared based on estimates from CONEVAL (2018)

Table 5 reflects that the highest percentage of the population with income below the extreme poverty line by income was presented in the state of Chiapas corresponding to $48.99 \%$, followed by Guerrero and Oaxaca with $38.67 \%$ and $38.22 \%$ respectively, while the The lowest percentage represented by $13.04 \%$ was registered in the state of Quintana Roo. 


\begin{tabular}{|l|c|r|r|r|r|}
\hline $\begin{array}{c}\text { Federal } \\
\text { entity }\end{array}$ & $\mathbf{2 0 1 0}$ & $\mathbf{2 0 1 2}$ & $\mathbf{2 0 1 4}$ & $\mathbf{2 0 1 6}$ & Average \\
\hline Campeche & 21.617 & 20.563 & 19.199 & 15.770 & 19.29 \\
\hline Chiapas & 50.891 & 46.705 & 48.458 & 49.884 & 48.99 \\
\hline Warrior & 38.760 & 45.127 & 35.578 & 35.193 & 38.67 \\
\hline Oaxaca & 36.202 & 34.387 & 42.106 & 40.202 & 38.22 \\
\hline Puebla & 27.658 & 32.943 & 31.853 & 23.115 & 28.89 \\
\hline $\begin{array}{l}\text { Quintana } \\
\text { Roo }\end{array}$ & 12.054 & 16.562 & 14.302 & 9.258 & 13.04 \\
\hline Tabasco & 22.380 & 23.625 & 17.871 & 19.569 & 20.86 \\
\hline Veracruz & 27.773 & 24.026 & 29.184 & 30.566 & 27.89 \\
\hline Yucatan & 17.889 & 16.619 & 20.715 & 11.775 & 16.75 \\
\hline
\end{tabular}

Table 5 Percentage of population with income below the extreme poverty line by income in the states of southeastern Mexico for the period 2010-2016 Source: Prepared based on estimates from CONEVAL (2018)

For its part, Table 6 shows that the highest percentage of the population with an income below the income poverty line was registered in the state of Chiapas with $78.95 \%$, followed by Guerrero, Oaxaca and Puebla, with $69.25 \%, 68.36 \%$ and $67.76 \%$ respectively; while the lowest percentage was located in the state of Quintana Roo.

\begin{tabular}{|l|c|c|c|c|r|}
\hline $\begin{array}{c}\text { Federal } \\
\text { entity }\end{array}$ & $\mathbf{2 0 1 0}$ & $\mathbf{2 0 1 2}$ & $\mathbf{2 0 1 4}$ & $\mathbf{2 0 1 6}$ & Average \\
\hline Campeche & 54.825 & 50.236 & 47.585 & 48.564 & 50.30 \\
\hline Chiapas & 80.853 & 76.418 & 78.705 & 79.808 & 78.95 \\
\hline Warrior & 69.549 & 71.946 & 67.865 & 67.624 & 69.25 \\
\hline Oaxaca & 68.282 & 63.593 & 68.845 & 72.729 & 68.36 \\
\hline Puebla & 67.050 & 68.690 & 69.657 & 65.646 & 67.76 \\
\hline $\begin{array}{l}\text { Quintana } \\
\text { Roo }\end{array}$ & 39.365 & 44.983 & 42.133 & 33.158 & 39.91 \\
\hline Tabasco & 61.228 & 52.696 & 51.919 & 53.445 & 54.82 \\
\hline Veracruz & 62.106 & 56.629 & 63.023 & 67.133 & 62.22 \\
\hline Yucatan & 54.759 & 55.108 & 52.811 & 47.614 & 52.57 \\
\hline
\end{tabular}

Table 6 Percentage of population with income below the income poverty line in the states of southeastern Mexico for the period 2010-2016

Source: Prepared based on estimates from CONEVAL (2018)

\section{Conclusions}

In the study carried out, it was possible to identify that, as Aguilar-Ortega (2011) points out, in Mexico there are regions that concentrate a large part of the wealth in a small number of people and areas where the situation is opposite, creating serious imbalances, particularly in the region southeast of the country.
The analysis of the indicators under study shows that the southeast region of Mexico is an area with high inequality in the distribution of income, registering an average percentage of inequality of $48 \%$ based on the estimate of the Gini coefficient for the period 2010-2016, presenting a tendency to increase for subsequent years. Therefore, the income disparity in the Mexican southeast is generating a larger population in a situation of poverty and vulnerability, which coincides with that reported by Cortés (2013) who points out that, in Mexico, economic inequality prevails in its population, particularly in Mexico. certain geographical areas.

In this sense, it was identified that this inequality has a significant impact on the state of Chiapas, where despite having registered a gradual decrease in the Gini coefficient during the period studied, it continues to hold the first place in economic inequality in the southeast of the country with an average of $51 \%$. In addition, this federative entity registered the highest percentage of vulnerability and lag in four of the evaluated indicators: population in a situation of poverty represented by $76.62 \%$, population in extreme poverty corresponding to $32.59 \%$, population with an income below the extreme poverty line by income with $48.99 \%$ and population with income below the poverty line by income through $78.95 \%$. These findings coincide with those found by Levy et al. (2015) who point out that in Chiapas the per capita income is the lowest and also rank it as the state with the highest poverty and extreme poverty in the country.

Likewise, it was identified that Guerrero and Oaxaca are the two states that are most likely to present a situation similar to that of Chiapas, since they recorded values of poverty in general and economic inequality very close to those obtained by Chiapas in the aforementioned indicators. In this sense, it should be noted that, since the beginning of this century, Sánchez (2006) reported that Chiapas, Guerrero, and Oaxaca are the southern states with the highest levels of poverty and lag in the areas of health, education and housing; however, 10 years after having identified this problem and submitted proposals; In the present research, it was found that these states continue to occupy the first places of backwardness and poverty in the region. 
On the other hand, the state of Quintana Roo stood out for being the state with the least economic inequality and the lowest levels of poverty in general, which is assumed to be related to the tourist activities that have boosted its economy during the period studied, since according to Gutiérrez-Pérez et al. (2014) it is considered that tourism is a possibility for the development of economically less favored areas.

The distribution of wealth despite being a topic on the agendas of International Organizations such as the United Nations, the Organization for Economic Cooperation and Development, the International Monetary Fund and the World Bank; It has not been able to be totally solved, and it is that the National Development Plan, the State and Municipal Development Plans include a series of public policies for the generation of jobs, business competitiveness and social development; through programs and actions such as transfers, scholarships and social assistance; However, they have not been enough to cover the entire population, which grows geometrically.

Although the economy mentions that resources are scarce, the truth is that these being used in a rational way can generate a positive impact on the population. The southeast region of the country has natural and non-renewable resources such as hydrocarbons, which can generate the necessary conditions for development. Tourism, agriculture, livestock, oil and natural gas extraction are some of the predominant economic activities in the region, in addition, states such as Puebla and Yucatan have industrialized, exporting a large amount of manufacturing.

Economic development is achieved with a balanced income distribution, since, in Mexico, a large part of the capital is concentrated in a small number of people (Sánchez 2006). Mexico, its governments and social actors have the fundamental role of seeking that present and future generations have what is necessary for their well-being. Every day, economic science generates more information that can be used for the implementation of policies, which is why a deep, objective and truthful analysis of this data is required.
The recommendations that emerge from this study for a better income distribution and poverty reduction in the southeast region of Mexico are the following:

- Promote the generation of decent employment with fair remuneration, which helps the minimum wage to ensure the well-being of the most vulnerable population by income.

- Design and implementation of income redistributive policies in favor of the most disadvantaged population and sectors in the areas of education, health, energy and housing.

- $\quad$ Provide the population with free public resources that suit their needs.

- $\quad$ Promote food security and quality of life.

- Implementation of a more transparent social program evaluation system.

Likewise, future research suggests analyzing the social deprivation indicator, which considers the following parameters: deficiencies in access to health services, social security, quality and spaces in housing, basic services in housing, food, and educational lag. In addition, it is recommended to make a comparison between the regions that have had a greater participation in economic globalization and that belong to the less unequal areas of Mexico. The above in order to identify the existing gap between the regions with a fairer income distribution and that therefore generates a better quality of life for its inhabitants.

\section{References}

Abramo, L., Cecchini, S., \& Morales, B. (2019). Desarrollo Social Programas sociales, superación de la pobreza e inclusión laboral. Naciones Unidas, Santiago. Recuperado de www.cepal.org/apps

Aguilar, T. (2016). Desigualdad y Marginación en Chiapas. Península, Vol. XI, n, 143-159. Recuperado de https://www.elsevier.es/esrevista-peninsula-108-pdf-S1870576616300071 
Aguilar-Ortega, T. (2011). Desarrollo industrial nacional y regional: un referente empírico. Agricultura, sociedad y desarrollo, 345-366.

Atuesta, B., Mancero, X., \& Tromben, V. (2018). Herramientas para el Análisis de las Desigualdades y del Efecto Redistributivo de las Políticas Públicas. (CEPAL, Ed.). Santiago de Chile. Recuperado de www.cepal.org/es/suscripciones

Bárcena, A. (2011). Distribuir la riqueza. Finanzas \& Desarrollo, 20-21.

Barcelata, H. (2008). La economía mexicana, crisis y reforma estructural. Malaga: Universidad de Málaga.

Borri, N. (2009). Distribución de riqueza. Buenos Aires: Centro Nueva TierraCoordinador Colectivo Ciudadanía.

Campos, R., \& Monroy-Gómez-Franco, L. (2016). La relación entre crecimiento económico y pobreza en México. Investigacion Economica, 75(298), $77-113$ https://doi.org/10.1016/j.inveco.2016.11.003

Capdepont-Ballina, J., \& Marín-Olán, P. (2014). La economía de Tabasco y su impacto en el crecimiento urbano de la ciudad de Villahermosa. LiminaR, 144-160.

Colegio de México [CM] (2018). Inequality in Mexico 2018. México.

Comisión Económica para América Latina y el Caribe [CEPAL]. (2019). Panorama Social de América Latina 2018. Naciones Unidas, Santiago. Recuperado de www.cepal.org/es/suscripciones

Consejo Nacional de Evaluación de la Politica de Desarrollo Social [CONEVAL]. (2018). Anexo estadístico 2018. Recuperado el 13 de noviembre de 2020, de https://www.coneval.org.mx/Medicion/MP/Pag inas/AE_pobreza_2018.aspx

Consejo Nacional de Evaluación de la Politica de Desarrollo Social [CONEVAL]. (2014). Evolución de la desigualdad: CEPAL, OCDE, Banco Mundial. Recuperado de www.coneval.org.mx
Comité de Planeación para el Desarrollo del Estado de Tabasco [COPLADET]. (2019). Plan estatal de desarrollo 2019-2024. Plan estatal de desarrollo. Tabasco, México.

Comisión Económica para América Latina y el Caribe [CEPAL]. (2019). Panorama Social de América Latina 2018. Naciones Unidas, Santiago. Recuperado de www.cepal.org/es/suscripciones

Cortes, F. (2010). Medio siglo de desigualdad en el ingreso en Méxi. Journal Economic Literature, 12-34.

Cortés, F. (2013). Medio siglo de desigualdad en el ingreso en México. Economía UNAM, 10(29), 12-34. https://doi.org/10.1016/s1665952x(13)72193-5

Cortes, F., \& de Oliveira, O. (2010). Los grandes problemas de México. Desigualdad social. México: El Colegio de México.

Coutiño, A. (7 de septiembre de 2015). Expansión. Obtenido de Mexico y la desigualdad en la distribución de la riqueza: http://expansion.mx/opinion/2015/09/04/porque-persiste-la-desigualdad-de-ingresos-enmexico-i

Encalada-Encarnación, V., Ruiz-Quezada, S., \& Encarnación-Merchán, O. (2018). La Contabilidad financiera una disciplina maestra como fuente de información de las actividades económicas y cambio social sostenible. México.

Escutia, J. A. (2012). El crecimiento económico y el gasto público como amortiguador de la distribución regional del ingreso en México (Tesis, Universidad Nacional Autónoma de México). Recuperada de http://132.248.9.195/ptd2013/enero/300813786/ Index.html

Esquivel, G. (2015). Concentración del Poder Económico y Político Desigualdad Extrema en México. México.

Favila, A., \& Navarro, J. (2017). Desigualdad Educativa y su Relación con la Distribución del Ingreso en los Estados Mexicanos. Revista de Investigación Educativa 24. 
Fuentes-Nieva, R. (30 de marzo de 2016). Forbes. Obtenido de ¿La riqueza es problema para el desarrollo? La clave es la desigualdad: https://www.forbes.com.mx/riqueza-extrema/

Gauna, C. (2014). La Problemática de los Gobiernos Locales en México: un reto para el desarrollo local en zonas turísticas. DELOS, Vol 7. (18).

Gordillo, G. (2013). La desigualdad: un tatuaje que nos acompaña. Economía UNAM, 10(28), 102-123. https://doi.org/10.1016/s1665$952 \times(13) 72190-x$

Guerrero-de-Lizardi, C. (2015). An Imperfect Approach for Looking at the Distribution of Financial and Non-Financial Wealth in Mexico 1984-2012. Revista Mexicana de Economía y Finanzas, 10(2), 145-158. https://doi.org/10.21919/remef.v10i2.72

Girondella, L. (11 de septiembre de 2008). Contrapeso. Obtenido de Distribución de la riqueza:

http://contrapeso.info/2008/distribucion_de_la_ riqueza/

Guzmán , A., \& et. al. (2012). Turismo: Enfoque global. Villahermosa: UJAT.

Gutiérrez-Pérez, F., Medina-Muñoz, D., \& Medina-Muñoz, R. (2014). Turismo y alivio de la pobreza: una revisión de la literatura académica. Tourism \& Management Studies, 10(2), 104-115. Recuperado de https://www.redalyc.org/articulo.oa? $\mathrm{id}=388743$ 882013

Halter, D., Oechslin, M., \& Zweimüller, J. (2014). Inequality and growth: The neglected time dimension. Journal of Economic Growth, 19(1), 81-104. https://doi.org/10.1007/s10887013-9099-8

Hernández, G. (2013). El desarrollo económico en México. Estudios, 100-140.

Instituto Nacional de Estadística y Geografía [INEGI]. (2015). Encuesta Nacional de Ingresos y Gastos de los Hogares (ENIGH) 2014. Recuperado de

http://www.beta.inegi.org.mx/proyectos/enchog ares/regulares/enigh/tradicional/2014/default.ht $\mathrm{ml}$
Jáuregui, E., Tello, D. y Rivas, G. (2012). Desigualdad y política ambiental en México. Economía mexicana nueva época, 21(2), 251275.

Levy, D., Hausmann, R., Santos, M., Espinoza, L., \& Flores, M. (2016). Why Is Chiapas Poor?

María, J., Munive, J., \& Munive, C. (2019). El Clientelismo Político y Corruptor como Cultura de Participacion Asimétrica y Légitima Autores. TLATEMOANI Revista Académica de Investigación (Vol. No. 32). Recuperado de https://www.eumed.net/rev/tlatemoani/index.ht $\mathrm{ml}$

Martínez, M. (2008). Métodos de medición de la pobreza y distribución del ingreso en México. Disertación de Licenciatura, UNAM, México.

Mckenzie, D., \& Rapoport, H. (2004). Stanford: Department of Economics, Stanford University.

Medina-Argueta, G., \& Palafox-Muñoz, A. (2019). Estructuras sustentables de desarrollo como alternativas en las comunidades cercanas a los destinos turísticos de Quintana Roo. Investigaciones Turísticas, (18), 1. https://doi.org/10.14198/inturi2019.18.01

Medina, F. (2001). Consideraciones sobre el índice de Gini para medir la concentración del ingreso. Santiago de Chile.

Mendoza, H. (2011). El concepto de pobreza y su evolución en la política social del gobierno mexicano. Estudios Sociales, 19(37), 222-251.

Mora-Rivera, J., \& Morales, F. (2018). Remesas y pobreza: una revisión teórica y empírica. Economía Teoría y Práctica Nueva Época, 48, 197-230.

https://doi.org/10.24275/ETYPUAM/NE/48201 8/Mora

Moreno, J. (11 de abril de 2013). La distribución de la riqueza, el país y la desigualdad en el mundo. Obtenido de El tribuno: http://www.eltribuno.info/salta/nota/2013-4-1122-19-0-la-distribucion-de-la-riqueza-el-pais-yla-desigualdad-en-el-mundo

Navarrete, J. (2016). ¿Desigualdad y crecimiento? Journal of Economic Literature, 13(37), 45-73. https://doi.org/10.1016/j.eunam.2016.02.002

SALVADOR-GARCÍA, Yazmin Denisse, MAY-GUILLERMO, Erika Guadalupe and DE LA CRUZ-MAY, Samuel. Income disparity in southeastern Mexico: A reflection from economic indicators. RINOE Journal-Financial Economy. 2020. 
Organización para la Cooperación y el Desarrollo Económicos [OECD]. (2018). Perspectivas económicas de América Latina 2018 -Repensando las Instituciones para el Desarrollo. PARÍS. https://doi.org/10.1787/leo2018-es

Organización para la Cooperación y Desarrollo Económicos [OCDE]. (2012). México: Mejores politicas para un desarrollo incluyente. México.

Ordóñez, G. (2018). Discriminación, pobreza y vulnerabilidad: los entresijos de la desigualdad social en México. REGIÓN Y SOCIEDAD, XXX (71). https://doi.org/10.22198/rys.2018.71.a377

Organización Internacional del Trabajo [OIT]. (2017). Informe Mundial sobre Salarios 2016/2017. Ginebra.

Ortiz, I., \& Cummins, M. (2012). DESIGUALDAD GLOBAL: La distribución del ingreso en 141 países.

Pozas, M. d. (2010). El contexto de la desigualdad internacional y el problema del desarrollo. En F. Cortes, \& O. de Oliveira, Los grandes problemas de México: Desigualdad Social (págs. 29-60). México: Colegio de México, A.C.

Puryear, J. y Malloy, M. (2010). La política fiscal y los pobres en América Latina. Washington: The Inter-American Dialogue.

Rosales, M. (2017). El Desarrollo Humano: una propuesta para su medición. Aldea Mundo, 22(1), 2017.

Rivera, R., \& González, N. (2017). Saberes Tradicionales, Ecoturismo, Salud Ambiental y Participación Comunitaria: Hacia el Desarrollo Endógeno. Málaga, España.

Samuelson, P. y Nordhaus, W. (2002). Economía. Madrid: Mc Graw Hill.

Sánchez, A. (2006). Crecimiento económico, desigualdad y pobreza: una reflexión a partir de Kuznets. Problemas del Desarrollo. Revista Latinoamericana de Economía, 37(145). https://doi.org/10.22201/iiec.20078951e.2006.1 45.7613
Sánchez, A. (2009). Crecimiento económico, desigualdad y pobreza: una reflexión a partir de Kuznets. Problemas del Desarrollo. Revista Latinoamericana de Economía, 37(145), 11-30. https://doi.org/10.22201/iiec.20078951e.2006.1 45.7613

Secretaría de Economía [SE]. (2020). Secretaría de Economía - Factores de producción. Recuperado el 14 de noviembre de 2020, de http://www.2006-

2012.economia.gob.mx/economia-paratodos/abc-de-economia/8357-factores-deproduccion

Secretaría de Agricultura, Ganadería, Desarrollo Rural, Pesca y Alimentación de México [SAGARPA]. (2011). Región Sur Sureste: Campeche, Chiapas, Oaxaca, Quintana Roo, Tabasco, Veracruz y Yucatan. Vocación y Desarrollo. México: SAGARPA.

Secretaría de Desarrollo Agrario, Territorial y Urbano [SEDATU]. (2014). Programa regional de desarrollo del sur-sureste. México.

Tezanos, S., Quiñones, A., Gutierrez, D., \& Madrueño, R. (2013). Desarrollo Humano, Pobreza y Desigualdades. España. Recuperado de www.clacso.edu.ar

Vielma, H. (2011). Distribución del ingreso y desarrollo económico: el marco teórico. Comercio exterior, 857-861. 